\title{
THE SENSITIVITY OF VARIOUS BACTERIA TO ANTIBIOTICS DURING THE YEARS 1951 TO 1956
}

\author{
BY \\ C. GILES AND EILEEN M. SHUTTLEWORTH \\ From the Pathology Department, City General Hospital, Stoke-on-Trent
}

(RECEIVED FOR PUBlication AUGUST 30, 1957)

Since the beginning of 1951 a record has been kept of the sensitivity to available antibiotics of most common bacterial pathogens isolated from routine material in the clinical laboratory of a large provincial general hospital. The most commonly tested organisms included Staphylococcus pyogenes aureus (Staph. aureus), Escherichia coli (E. coli), Pseudomonas pyocyanea, and members of the Proteus and Klebsiella group of organisms. An analysis follows of the results of the sensitivity tests carried out during the six years from 1951 to 1956 on these bacterial species.

\section{Technique}

Qualitative methods form the basis of this study. At the outset filter paper strip methods were employed. During the course of time, however, this practice was abandoned in favour of the dried filter paper disc technique (Thompson, 1950 ; Fairbrother, Martyn, and Parker, 1951). When standard antibiotic test tablets (Evans's "sentests") became available for most of the commoner drugs these were substituted for filter paper discs, since it was found that far more consistent and reliable results were thus obtained. These tablets contain the following concentrations of the different antibiotics:

\begin{tabular}{|c|c|c|c|c|c|}
\hline Penicillin $\quad \ldots$ & . & 2.5 & Oxford units & per & tablet \\
\hline Streptomycin & . & 20 & $11 \mathrm{~g}$ & .. & ," \\
\hline Aureomycin & . & 100 & ,. & .. & ," \\
\hline Terramycin & . & 100 & .. & , & , \\
\hline Tetracycline & .. & 100 & & .. & ,, \\
\hline Chloramphenizol & $\ldots$ & 40 & .. & ., & ., \\
\hline Erythromycin & . & 10 & .. & .. & , \\
\hline
\end{tabular}

In the case of polymyxin B dried paper discs each containing $150 \mu \mathrm{g}$. were used. An organism was judged sensitive if a zone of inhibition of $10 \mathrm{~mm}$. radius or more surrounded the tablet or paper disc. Media employed consisted mainly of blood agar for Staph. aureus and MacConkey's bile salt agar for the Gram-negative bacteria. Results were read after 15 to 18 hours' incubation. For sulphonamide sensitivity of $E$. coli the method of Jewell and Pearmain (1954) was adopted.

\section{Staphylococcus Aureus}

Altogether 1,565 strains were examined. These were derived from the following sources:

\begin{tabular}{|c|c|c|c|c|c|c|c|}
\hline Wounds, abscess & ses, & septic & skin & lesions & $\cdots$ & $\cdots$ & 671 \\
\hline Eye swabs & . & $\cdots$ & - & . & . & - & 429 \\
\hline Sputum $\ldots$ & . & & - & . & $\cdots$ & $\cdots$ & 124 \\
\hline Urinary infection & & $\cdots$ & . & $\cdots$ & . & . & 121 \\
\hline Vaginal swabs & . & . & - & . & . & $\cdots$ & 75 \\
\hline Nose and throat & . & - & . & . & .. & . & 66 \\
\hline Blood culture & .. & . & . & .. & . & $\cdots$ & \\
\hline Elsewhere .. & .. & .. & . & . & .. & . & 53 \\
\hline
\end{tabular}

As Barber (1947), Forbes (1949), and others have pointed out, most penicillin-resistant strains originate in hospital, and the same probably holds true for resistance to other antibiotics. Unfortunately, it was not possible in such a large series extending over several years to be certain in every case whether infection originated in hospital or outside. However, the majority of specimens was taken from in-patients, and it can be assumed that a high proportion of these were in fact suffering from hospital infections. In any case, the proportion of in-patients to out-patients from whom bacteriological specimens were taken has remained the same between 1951 and 1956. A valid comparison is therefore possible between the figures for each year.

Results.-The results of antibiotic sensitivities of Staph. aureus are summarized in Table I, and the more striking changes in Fig. 1. Most of the strains resistant to several antibiotics were also penicillin-resistant, as already observed by Clarke, Dalgleish, and Gillespie (1952). There has been a marked increase since 1955 of strains resistant to three or more antibiotics, as shown by the following figures:

$\begin{array}{lllrc}1951 & . . & . & 6 & \text { strains } \\ 1952 & . & . . & 6 & . . \\ 1953 & . & . . & 19 & . \\ 1954 & \ldots & . . & 14 & . \\ 1955 & . . & . . & 42 & . . \\ 1956 & . . & . . & 62 & . .\end{array}$

A preliminary survey of results for the first four months of 1957 suggests that there will probably be a further sharp rise during the current year of staphylococcal strains resistant to many or most of 
TABLE I

SENSITIVITY OF STAPHYLOCOCCUS AUREUS TO ANTIBIOTICS

\begin{tabular}{|c|c|c|c|c|c|c|c|c|c|c|c|c|c|c|}
\hline \multirow[b]{2}{*}{ Year } & \multicolumn{2}{|c|}{ Penicillin } & \multicolumn{2}{|c|}{ Erythromycin } & \multicolumn{2}{|c|}{ Streptomycin } & \multicolumn{2}{|c|}{ Aureomycin } & \multicolumn{2}{|c|}{ Terramycin } & \multicolumn{2}{|c|}{ Tetracycline } & \multicolumn{2}{|c|}{ Chloramphenicol } \\
\hline & $\begin{array}{c}\text { Total } \\
\text { No. }\end{array}$ & Resistant & $\begin{array}{l}\text { Total } \\
\text { No. }\end{array}$ & Resistant & $\begin{array}{c}\text { Total } \\
\text { No. }\end{array}$ & Resistant & $\begin{array}{c}\text { Total } \\
\text { No. }\end{array}$ & Resistant & $\begin{array}{c}\text { Total } \\
\text { No. }\end{array}$ & Resistant & $\begin{array}{c}\text { Total } \\
\text { No. }\end{array}$ & Resistant & $\begin{array}{c}\text { Total } \\
\text { No. }\end{array}$ & Resistant \\
\hline $\begin{array}{l}1951 \\
1952 \\
1953 \\
1954 \\
1955 \\
1956\end{array}$ & $\begin{array}{l}157 \\
232 \\
288 \\
285 \\
279 \\
302\end{array}$ & $\begin{array}{l}64 \\
68 \\
73 \\
59 \\
72 \\
68\end{array}$ & $\begin{array}{l}242 \\
280 \\
294\end{array}$ & $\begin{array}{l}1 \\
2 \\
1\end{array}$ & $\begin{array}{l}153 \\
232 \\
289 \\
280 \\
283 \\
302\end{array}$ & $\begin{array}{r}17 \\
16 \\
18 \\
9 \\
20 \\
33\end{array}$ & $\begin{array}{l}157 \\
232 \\
280 \\
269 \\
284 \\
300\end{array}$ & $\begin{array}{r}6 \\
4 \\
8 \\
6 \\
15 \\
24\end{array}$ & $\begin{array}{l}280 \\
278 \\
276 \\
302\end{array}$ & $\begin{array}{r}8 \\
6 \\
18 \\
22\end{array}$ & $\begin{array}{l}156 \\
302\end{array}$ & $\begin{array}{l}15 \\
23\end{array}$ & $\begin{array}{l}128 \\
232 \\
276 \\
282 \\
286 \\
303\end{array}$ & $\begin{array}{r}4 \\
5 \\
5 \\
5 \\
6 \\
10\end{array}$ \\
\hline $\begin{array}{c}\text { Total } \\
1951 \text { to } \\
1956\end{array}$ & 1.543 & 68 & 816 & 1 & 1,539 & 19 & 1,522 & 11 & 1,136 & 14 & 458 & 21 & 1.507 & 6 \\
\hline
\end{tabular}

the common antibiotics. Three strains of this type during the latter half of 1956 caused fulminating entero-colitis and two of these cases were fatal.

In recent months all antibiotic-resistant staphylococci have also been tested against novobiocin. oleandomycin, and spiramycin, but no resistance to any of these newer antibiotics has as yet been encountered. According to these figures, penicillinresistance, though fiuctuating between 59 and $73 \%$. has not shown a steady rise as in earlier years. Thus Barber and Rozwadowska-Dowzenko (1948) found an increase from $14 \%$ in 1946 to $59 \%$ in 1948. But already in 1953 Needham and Nichols noted that penicillin-resistance among staphylococci had not substantially increased between
1948 and 1952. Penicillin-resistance at different times has been quoted as $42 \%$ (Fairbrother et al., $\vec{\infty}$ 1951), 10\% (MacFarlane, 1951), 60-80\% (Kenney. o Johnson, and Tatz, 1953), 43-70\% (Weil and Stempel, 1953), 70\% (Kirby and Ahern. 1953). and $\frac{z}{z}$ 82 ․ (Rantz and Rantz. 1956).

Resistance to streptomycin in the present series $\stackrel{\widehat{S}}{ح}$ has, however, increased since 1955, and there is a $\overrightarrow{0}$ well-marked rise in the resistance to the tetracyclines during the last two years of this survey. Chloramphenicol has shown the same trend, but to a much lesser degree. Many authors, especially in America, reported similar changes several years ago (Needham and Nichols, 1953: Weil and Stempel, 1953: Kenney et al.. 1953). A recent $\stackrel{\mathbb{Q}}{2}$

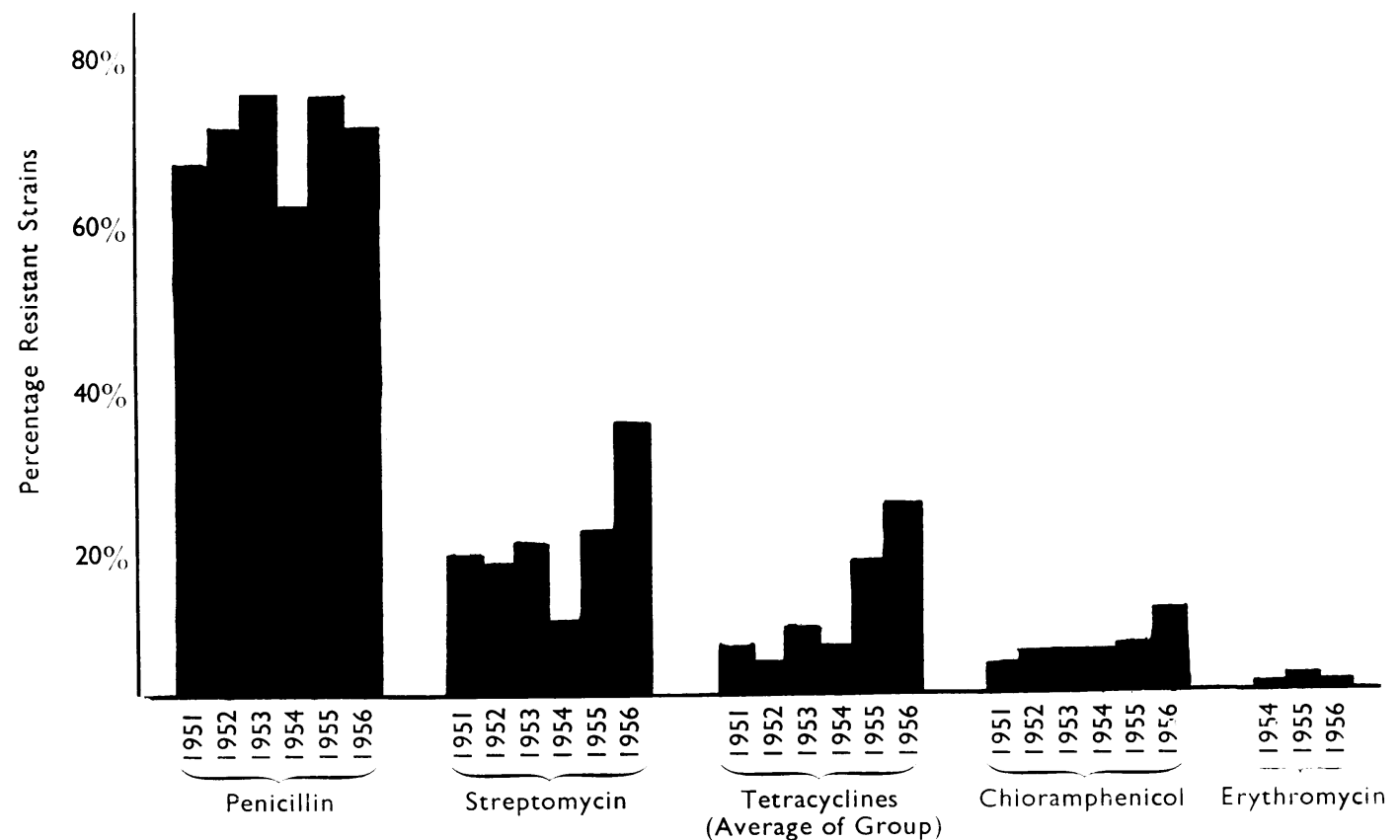

Fro. 1 
review by Rantz and Rantz (1956) showed over half their strains of Staph. aureus to be resistant to streptomycin and tetracycline, while less than $6 \%$ were chloramphenicol resistant.

Although erythromycin has been freely available for nearly four years, resistance to this drug has not as yet presented a serious problem in this hospital, although Rantz and Rantz (1956) already reported a $6.6 \%$ resistance rate. One of the reasons for the continued efficacy of erythromycin in staphylococcal infections may have been its restricted use by the hospital medical staff. A conscious effort was made to use this antibiotic only in cases infected with staphylococci resistant to other drugs and in staphylococcal infections of young children or very seriously ill patients. Since the newer antibiotics such as novobiocin, oleandomycin, and spiramycin can now be obtained it might be tempting to use erythromycin more freely. However, there is already some evidence (Lancet, 1957) that resistance to at least two of the new drugs may result in cross-resistance to erythromycin.

\section{Escherichia Coli}

The total number of strains examined was 2,827 . They were derived from the following sources:

$\begin{array}{lcccr}\text { Urinary infections } & \ldots & \ldots & 2,062 \\ \text { Wounds, abscesses, ulcers } & \ldots & 398 \\ \text { Vaginal swabs } & . & \ldots & \ldots & 167 \\ \text { Elsewhere } & . & \ldots & \ldots & 200\end{array}$

Tetracycline sensitivity tests were not performed regularly until 1954 and the figures for 1951-53 have therefore been omitted.

Results.-These are set out in Table II. In addition, 537 strains were tested for sensitivity to three sulphonamides (sulphathiazole, sulphadiazine, and sulphadimidine). Of these, $17 \%$ were resistant to all three drugs, and $63 \%$ to one or two.

It is evident that in this series there has been no significant increase in the resistance of $E$. coli to the commoner antibiotics. The slightly higher rate of resistance to aureomycin as compared with the other two tetracyclines may at first sight appear rather puzzling. However, partial drug resistance of organisms, especially to the tetracyclines, is not uncommon. By definition an organism is classed here as sensitive to a drug if the zone of inhibition was $10 \mathrm{~mm}$. radius or more. Some strains, however, show a somewhat smaller zone of inhibition and are therefore listed as resistant strains. Such a division is, of course, an arbitrary one and may explain this apparent anomaly.

If sensitivity in vitro is any guide, chloramphenicol is the most, and streptomycin the least, effective of the antibiotics under review. These findings are consistent with earlier work by Fairbrother et al. (1951) and May and Morley (1952). Most American workers record a significantly higher resistance rate. Thus Horton and Knight (1955) found $27-33 \%$ of urinary strains of $E$. coli resistant to chloramphenicol and up to $88 \%$ resistant to the tetracyclines and streptomycin ; earlier, in 1953 , Weil and Stempel recorded $10-17 \%$ resistant strains in the case of chloramphenicol, up to $54 \%$ for the tetracyclines, and $45-64 \%$ for dihydrostreptomycin. In the series published by Rantz and Rantz (1956) about $40 \%$ of all E. coli strains were resistant to streptomycin and tetracycline, while $34 \%$ were chloramphenicol resistant. They also found an increase in the rate of antibiotic resistance over a five-year period. Most workers agree with Perry (1955) that chloramphenicol is still the most effective antibiotic against $E$. coli.

Proteus.-Altogether 463 strains were examined, most of which were $P$. vulgaris, although a small number of specimens yielded $\boldsymbol{P}$. mirabilis and $\boldsymbol{P}$. rettgeri. They were derived as follows:

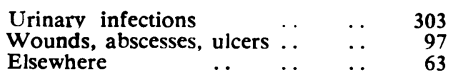

The number of Proteus strains isolated from sites where they were considered pathogenic has steadily increased since 1951. Although the

TABLE II

SENSITIVITY OF ESCHERICHIA COLI TO ANTIBIOTICS

\begin{tabular}{|c|c|c|c|c|c|c|c|c|c|c|c|c|}
\hline \multirow{2}{*}{\multicolumn{3}{|c|}{ Year }} & \multicolumn{2}{|c|}{ Streptomycin } & \multicolumn{2}{|c|}{ Aureomycin } & \multicolumn{2}{|c|}{ Terramycin } & \multicolumn{2}{|c|}{ Tetracycline } & \multicolumn{2}{|c|}{ Chloramphenicol } \\
\hline & & & $\begin{array}{c}\text { Total } \\
\text { No. }\end{array}$ & $\begin{array}{c}\% \\
\text { Resistant }\end{array}$ & $\begin{array}{c}\text { Total } \\
\text { No. }\end{array}$ & $\begin{array}{c}\% \\
\text { Resistant }\end{array}$ & $\begin{array}{l}\text { Total } \\
\text { No. }\end{array}$ & $\begin{array}{c}\% \\
\text { Resistant }\end{array}$ & $\begin{array}{c}\text { Total } \\
\text { No. }\end{array}$ & $\begin{array}{c}\% \\
\text { Resistant }\end{array}$ & $\begin{array}{c}\text { Total } \\
\text { No. }\end{array}$ & $\begin{array}{c}\% \\
\text { Resistant }\end{array}$ \\
\hline $\begin{array}{ll}1951 & \ldots \\
1952 & \ldots \\
1953 & \ldots \\
1954 & \ldots \\
1955 & \ldots \\
1956 \ldots\end{array}$ & $\begin{array}{l}\ldots \\
\ldots \\
\ldots \\
\cdots \\
\cdots\end{array}$ & $\begin{array}{l}\ldots \\
\ldots \\
\ldots \\
\ldots \\
\ldots\end{array}$ & $\begin{array}{l}342 \\
395 \\
433 \\
510 \\
466 \\
430\end{array}$ & $\begin{array}{r}18 \\
8 \\
8 \\
17 \\
13 \\
13\end{array}$ & $\begin{array}{l}449 \\
459 \\
431\end{array}$ & $\begin{array}{r}13 \\
9 \\
6\end{array}$ & $\begin{array}{l}500 \\
464 \\
427\end{array}$ & $\begin{array}{l}\mathbf{8} \\
\mathbf{3} \\
3\end{array}$ & $\begin{array}{l}399 \\
421\end{array}$ & $\begin{array}{l}9 \\
3\end{array}$ & $\begin{array}{l}322 \\
394 \\
423 \\
507 \\
468 \\
428\end{array}$ & $\begin{array}{l}7 \\
4 \\
2 \\
5 \\
2 \\
2\end{array}$ \\
\hline \multicolumn{3}{|c|}{ Total 1951 to $1956 \ldots$} & 2,576 & 13 & 1,339 & 9 & 1,391 & 5 & 820 & 6 & 2,542 & 3 \\
\hline
\end{tabular}


TABLE III

SENSITIVITY OF PROTEUS TO ANTIBIOTICS

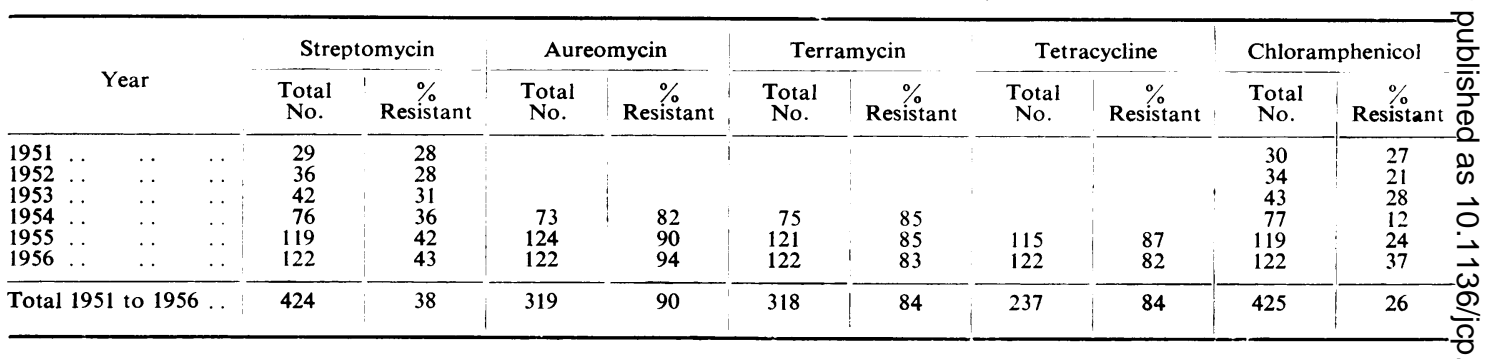

reason for this higher incidence is not altogether clear, the popularity of the tetracyclines may have favoured the survival of this type of organism in places like hospital wards where they may remain as endemic foci of hospital infection.

Results.-Results of sensitivity tests are shown in Table III. From these it is clear that only chloramphenicol and, to a lesser degree, streptomycin were effective against this group of organisms. There has, however, been a slight but steadily increasing drug resistance in the case of streptomycin and, in 1956, also to chloramphenicol. Only a minority of strains were inhibited by the tetracyclines. Nitrofurantoin has also been tested for a number of years, but only on rare occasions has it been found effective against strains resistant to the common antibiotics. Most organisms exhibiting universal drug resistance were isolated from cases of long-standing urinary infections in elderly males with prostatic disease, all of whom had received previous drug therapy. Neomycin has only recently been tried, but the number of tests are as yet too small to warrant publication.

British reviews (Fairbrother et al., 1951; May and Morley, 1952) produced similar results, whereas more recent American papers (Weil and Stempel, 1953 ; Horton and Knight, 1955 ; and Rantz and Rantz, 1956) found a rather higher rate of drug resistance. Unlike Poole (1954) and Potee, Wright, and Finland (1954) no constant drug sen- sitivity patterns for the different biochemical types $\overrightarrow{\vec{n}}$ of Proteus were found.

\section{Pseudomonas Pyocyanea}

A total of 195 strains are included. Their $\rightarrow$ sources were as follows:

$$
\begin{aligned}
& \text { Urinary infections } \\
& \text { Wounds, ulcers, etc } \\
& \text { Ears .. .. } \\
& \text { Elsewhere }
\end{aligned}
$$

Results.-Results of sensitivity tests are seen in ${ }^{\infty 0}$ Table IV. A fluctuating but uniformly high rate of drug resistance is evident from the figures in the present series. Unlike the Proteus group, Ps. pyocyanea is resistant to chloramphenicol evenơ more often than to the three tetracyclines and $\stackrel{\mathbb{Q}}{\varrho}$ streptomycin. The only antibiotic which was $\overrightarrow{\vec{\theta}}$ effective in inhibiting the growth of about four out 3 of every five strains of Ps. pyocyanea was polymyxin B. The present series thus confirms theo findings by Wright, Potee, and Finland (1954), but contrasts with those of Yow and Townsend (1953), ? who claim that $99 \%$ of strains were sensitive to $\frac{0}{3}$ polymyxin and $88 \%$ to terramycin.

\section{Klebsiella}

The broader definition by Kauffmann (1951) has응 been adopted for purposes of classification in the $D$ present study. In this group, therefore, are included all mucoid lactose- and inositol-ferment- N ing strains with a negative indole and a positive

TABLE IV

SENSITIVITY OF PS. PYOCYANEA TO ANTIBIOTICS

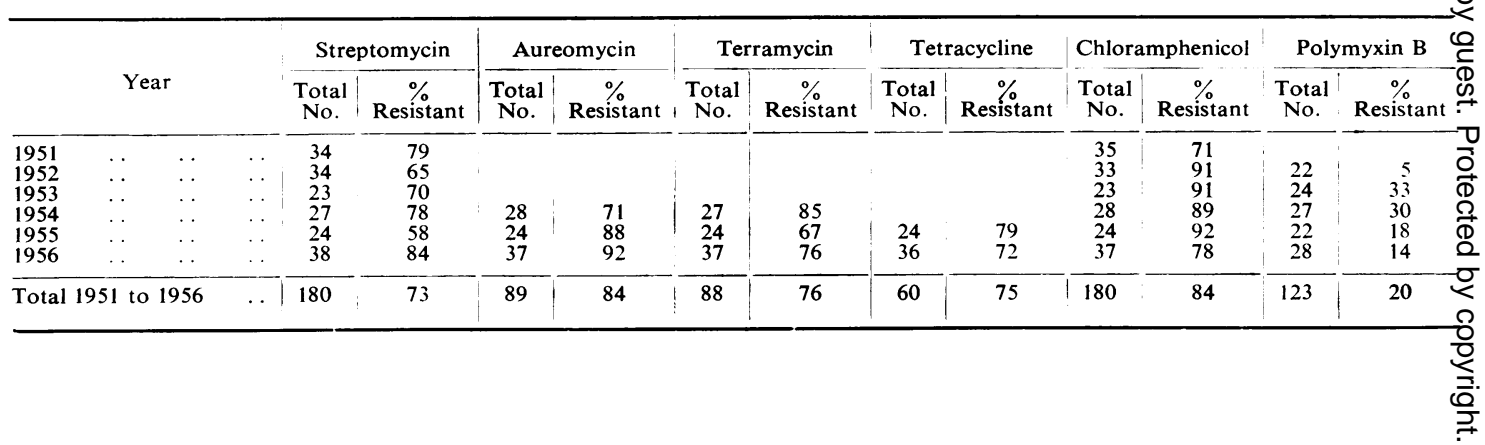


TABLE V

SENSITIVITY OF KLEBSIELLA TO ANTIBIOTICS

\begin{tabular}{|c|c|c|c|c|c|c|c|c|c|c|c|c|}
\hline \multirow{2}{*}{\multicolumn{3}{|c|}{ Year }} & \multicolumn{2}{|c|}{ Streptomycin } & \multicolumn{2}{|c|}{ Aureomycin } & \multicolumn{2}{|c|}{ Terramycin } & \multicolumn{2}{|c|}{ Tetracycline } & \multicolumn{2}{|c|}{ Chloramphenicol] } \\
\hline & & & $\begin{array}{l}\text { Total } \\
\text { No. }\end{array}$ & $\begin{array}{c}\% \\
\text { Resistant }\end{array}$ & $\begin{array}{c}\text { Total } \\
\text { No. }\end{array}$ & $\begin{array}{c}\% \\
\text { Resistant }\end{array}$ & $\begin{array}{l}\text { Totald } \\
\text { No. }\end{array}$ & $\begin{array}{c}\% \\
\text { Resistant }\end{array}$ & $\begin{array}{l}\text { Total } \\
\text { No. }\end{array}$ & $\begin{array}{c}\% \\
\text { Resistant }\end{array}$ & $\begin{array}{l}\text { Total } \\
\text { No. }\end{array}$ & $\begin{array}{c}\% \\
\text { Resistant }\end{array}$ \\
\hline $\begin{array}{l}1951 \ldots \\
1952 \ldots \\
1953 \ldots \\
1954 \ldots \\
1955 \ldots \\
1956 \ldots\end{array}$ & $\begin{array}{l}\ldots \\
\ldots \\
\ldots \\
\cdots \\
\cdots\end{array}$ & $\begin{array}{l}\ldots \\
\cdots \\
\cdots \\
\cdots \\
\cdots\end{array}$ & $\begin{array}{l}25 \\
39 \\
35 \\
13 \\
21 \\
46\end{array}$ & $\begin{array}{l}44 \\
59 \\
57 \\
39 \\
62 \\
35\end{array}$ & $\begin{array}{l}12 \\
20 \\
39\end{array}$ & $\begin{array}{l}42 \\
20 \\
13\end{array}$ & $\begin{array}{l}10 \\
20 \\
38\end{array}$ & $\begin{array}{r}10 \\
0 \\
11\end{array}$ & $\begin{array}{l}19 \\
37\end{array}$ & $\begin{array}{r}16 \\
8\end{array}$ & $\begin{array}{l}32 \\
39 \\
35 \\
13 \\
20 \\
38\end{array}$ & $\begin{array}{r}22 \\
10 \\
17 \\
8 \\
0 \\
8\end{array}$ \\
\hline \multicolumn{3}{|c|}{ Total 1951 to $1956 \ldots$} & 179 & 49 & 71 & 20 & 68 & 7 & 56 & 11 & 177 & 12 \\
\hline
\end{tabular}

Voges Proskauer reaction. The 191 strains were derived from the following sources:

\begin{tabular}{|c|c|c|c|c|}
\hline Urir & ctions & & & \\
\hline Spu & $\ldots$ & $\cdots$ & & \\
\hline $\begin{array}{l}\text { Wounds } \\
\text { Elsewher }\end{array}$ & & $\cdots$ & & . \\
\hline
\end{tabular}

Results.-Results of sensitivity tests, as seen in Table V, show that chloramphenicol and the tetracyclines are about equally effective and that there is no sign as yet of increasing rates of resistance. For reasons not understood, chloramphenicolresistant strains appear to have been diminishing in recent years rather than the reverse. Many of the urinary strains were streptomycin-resistant, whereas most strains of $K$. pneumoniae were sensitive to this antibiotic. The figures in the present series are in marked contrast to those published by Horton and Knight (1955) and Rantz and Rantz (1956) for Aerobacter aerogenes, since most strains in both American series were resistant to the common antibiotics.

\section{Summary and Conclusions}

The sensitivity of 5,241 common bacterial pathogens from 1951 to 1956 is reviewed.

The number of strains of Staphylococcus aureus resistant to penicillin during this period has remained fairly constant. Most strains are still sensitive to erythromycin and chloramphenicol, whereas the incidence of strains resistant to streptomycin and the tetracyclines has risen in recent years. The number of staphylococci showing resistance to three or more antibiotics has increased considerably.

There has been no significant rise in the rate of drug resistance of Escherichia coli to the commoner antibiotics. Chloramphenicol appears to be the most effective drug at present.

Members of the Proteus group are sensitive more often to chloramphenicol and streptomycin than to the tetracyclines, but the incidence of strains resistant to the first two is mounting.

Pseudomonas pyocyanea is usually resistant to most antibiotics with the exception of polymyxin B.

Of the Klebsiella group of organisms, most of the urinary strains showed marked resistance to streptomycin. Strains resistant to chloramphenicol and the tetracyclines were less frequent.

The incidence of antibiotic resistance in this series appears to be generally lower than in recent American surveys.

Our thanks are due to Mrs. Margaret Clowes, Mr. A. C. Key, F.I.M.L.T., Mr. P. H. Johnson, A.I.M.L.T., and Mr. R. Astbury, F.I.M.L.T., for technical assistance.

\section{REFERENCES}

Barber, M. (1947). Brit. med. J., 2, 863.

- and Rozwadowska-Dowzenko, M. (1948). Lancet, 2, 641.

Clarke, S. K. R., Dalgleish, P. G., and Gillespie, W. A. (1952). Ibid., 1,1132 .

Fairbrother, R. W., Martyn, G., and Parker, L. (1951). Ibid., 2, 516. Forbes, G. B. (1949). Brit. med. J., 2, 569.

Horton, B. F., and Knight, V. (1955). J. Tenn. med. Ass., 48, 367.

Jewell, P., and Pearmain, G. E. G. (1954). J. clin. Path., 7, 308.

Kauffmann, F. (1951). Enterobacteriaceae, p. 199. Munksgaard, Copenhagen.

Kenney, M., Johnson, P. M., and Tatz, J. S. (1953). Antibiot. and Chemother., 3, 1221 .

Kirby, W. M. M., and Ahern, J. J. (1953). Ibid., 3, 831.

Lancet (1957), 1, 723 (leader).

MacFarlane, J. C. W. (1951). Gt. Ormond Str. J., 1, No. 2, p. 118.

May, J. R., and Morley, C. W. (1952). Lancet, 1, 636.

Needham, G. M., and Nichols, D. R. (1953). J. Lab. clin. Med., 41, 150.

Perry, R. E. (1955). N.C. med. J., 16, 567

Poole, J. C. F. (1954). J. clin. Path., 7, 315.

Potee, K. G., Wright, S. S., and Finland, M. (1954). J. Lab. clin. Med., 44, 463.

Rantz, L. A., and Rantz, H. H. (1956). Arch. intern. Med., 97, 694.

Thompson, B. A. (1950). J. clin. Path., 3, 118.

Weil, A. J., and Stempel, B. (1953). Antibiot and Chemother., 3, 1135.

Wright, S. S., Potee, K. G., and Finland, M. (1954). Amer. J. clin. Path., 24, 1121.

Yow, E. M., and Townsend, E. S. (1953). Antibiot. and Chemother., 3, 709 . 